\title{
Handbook of Florida Water Regulation: Endangered Species Act ${ }^{1}$
}

Michael T. Olexa, Luke D'Isernia, Laura Minton, Dulcy Miller, and Sarah Corbett ${ }^{2}$

\section{Preface}

This handbook is designed to provide an accurate, current, and authoritative summary of the principle Federal and Florida laws that directly or indirectly relate to agriculture. This handbook should provide a basic overview of the many rights and responsibilities that farmers and farmland owners have under both Federal and Florida laws as well as the appropriate contact information to obtain more detailed information. However, the reader should be aware that because the laws, administrative rulings, and court decisions on which this handbook is based are subject to constant revision, portions of this publication could become outdated at anytime.

Several details of cited laws are also left out due to space limitations.

This handbook is distributed with the understanding that the authors are not engaged in rendering legal or other professional advice, and the information contained herein should not be regarded as a substitute for professional advice. This handbook is not all inclusive in providing information to achieve compliance with the Federal and Florida laws and regulations governing water protection. For these reasons, the use of these materials by any person constitutes an agreement to hold harmless the authors, the Florida Cooperative Extension Service, the Institute of Food and Agricultural Sciences, and the University of Florida for any liability claims, damages, or expenses that may be incurred by any person as a result of reference to or reliance on the information contained in this handbook.

\section{Overview}

The Endangered Species Act (ESA) was passed in 1974 to protect fish, wildlife, and plants that are threatened with extinction and the ecosystems that are determined critical to their survival. In many cases these ecosystems are wetlands, so endangered species protection often equals water protection.

\section{Who Enforces the ESA?}

The ESA requires all federal agencies to consult with an appropriate federal department (i.e.,

1. This is EDIS document FE592, a publication of the Food and Resource Economics Department, Florida Cooperative Extension Service, Institute of Food and Agricultural Sciences, University of Florida, Gainesville, FL. Published December 2005. Please visit the EDIS website at http://edis.ifas.ufl.edu.

2. Michael T. Olexa, Professor, Food and Resource Economics Department, Florida Cooperative Extension Service, Institute of Food and Agricultural Sciences, University of Florida, Gainesville, FL; Director, Agricultural Law Center, University of Florida, Gainesville, FL; and Chair, Agricultural Law Committee of The Florida Bar. Luke D'Isernia, former student (graduated cum laude in 2005), Levin College of Law, University of Florida, Gainesville, FL. Laura Minton, Attorney, Dean, Mead, Egerton, Bloodworth, Capouano, and Bozarth, Orlando, FL. Dulcy Miller, attorney, Foley and Lardner, LLP, Orlando, FL. Sarah Corbett, Attorney, Florida Second District Court of Appeal, Lakeland, FL.

The Institute of Food and Agricultural Sciences (IFAS) is an Equal Opportunity Institution authorized to provide research, educational information and other services only to individuals and institutions that function with non-discrimination with respect to race, creed, color, religion, age, disability, sex, sexual orientation, marital status, national origin, political opinions or affiliations. U.S. Department of Agriculture, Cooperative Extension Service, University of Florida, IFAS, Florida A. \& M. University Cooperative Extension Program, and Boards of County Commissioners Cooperating. Larry Arrington, Dean 
Department of the Interior, USDA) to determine what effects its land use or other actions will have upon endangered species. The agencies are prohibited from taking any action that will threaten an endangered species without a special waiver from a committee headed by the Secretary of the Interior.

Agency action might include the issuance of a permit to a private party such as when the Army Corps of Engineers issues permits for dredge and fill activities (see FE582, Clean Water Act). The ESA also applies to private and state actions although the prohibitions are slightly different.

The ESA grants enforcement authority to the Secretary of the Interior, the Secretary of Commerce and, in cases regarding the importation or exportation of plants, the Secretary of Agriculture. The Secretary of Agriculture is solely responsible for the protection of endangered plant species.

\section{What Laws Are Often Used to Help Enforce the ESA?}

\section{The National Environmental Policy Act (NEPA)}

NEPA, through the procedures it mandates, basically provides federal agencies the opportunity to stop and think of the environmental effects that will be caused by proposals for legislation and other major federal actions (projects) they propose before they commence the project. NEPA requires that all federal agencies must include in every recommendation or report on proposals for legislation and other major federal actions significantly affecting the quality of the human environment, a detailed written statement (Environmental Impact Statement) on:

- The environmental impact of the proposed action.

- Any adverse environmental effects which cannot be avoided if the proposal is implemented.

- Alternatives to the proposed action.

- The relationship between local short-term uses of man's environment and the maintenance and enhancement of long-term productivity.
- Any irreversible and irretrievable commitments of resources which would be involved in the proposed action if it was implemented.

The federal agencies' decision after performing an environmental impact statement (ESI) to make a ruling of no significant impact (FONSI), or if it does not perform an EIS due to a categorical exclusion, may be challenged and overturned by judicial review if the ageny fails to follow the rulemaking process as mandated under the Administrative Procedure Act (APA).

In situations where an EIS is not required for a federal agency's action because it is not a major federal action, it is due to a categorical exclusion, etc, the federal agency can choose to perform an Environmental Assessment (EA) on the project/proposal to determine whether the federal agency should perform an EIS on the specific project (a step frequently taken by agencies), or make a ruling of no significant impact (FONSI). Just like an EIS, a federal agency through an EA can make a ruling of no significant impact (FONSI).

\section{The Administrative Procedure Act (APA)}

The APA mandates the requirements the federal agencies must follow when they go through the process of making a rule. Basically, the rulemaking process requires that the federal agency determining whether or not to make a rule covering an aspect of its jurisdiction to first provide public notice, published in the Federal Register, of the proposed rule making which includes:

- The time, place, and nature of the public rulemaking proceedings.

- The legal authority under which the rule is being proposed.

- Either the terms of the rule or a description of the subject and issues involved.

Next, the federal agency must provide the public with an opportunity to be heard through participation in the rulemaking process by submission of written data, views, or arguments, with or without the opportunity of oral presentation. After considering all of the relevant matter presented, the federal agency 
must incorporate in the rule(s) adopted a general statement of their basis and purpose.

Finally, the federal agency must publish the substantive rule in the Federal Register no less than 30 days before its effective date.

If the federal agency fails to follow these requirements, the APA allows for judicial review of the agency's rule in some circumstances, but excludes judicial review if agency discretion is mandated by law. Only a person with standing may sue a federal agency for making a ruling.

The federal agency's violation of the requirements of NEPA can be addressed by the APA. This can prevent the federal agency from taking, or failing to take, an action that could negatively impact the environment or violate legislation such as the ESA.

\section{What Does the ESA Prohibit?}

The ESA prohibits the taking of any endangered species. "Taking" under the Act basically means killing, trapping, harassing, hunting, collecting, or harming the species in any way.

The definition of taking has been extended by the federal courts to include the destruction of areas designated as "critical habitats" where the destruction or adverse modification might be reasonably expected to result in a reduction in the number or distribution of an endangered species, especially if it hinders the endangered species' ability to feed, shelter, and/or reproduce. Any adverse modification or destruction of critical habitat is restricted under the ESA.

Non-point source pollution of such a habitat which leads to the destruction or adverse modification of the habitat and results in a reduction in the number or distribution of an endangered species could be considered as a taking of endangered species by the courts. The owner of that non-point source may then be liable for a violation of the ESA and face the penalties under the ESA.

\section{What Are the Penalties?}

Civil penalties may be enforced by any of the federal agencies in amounts of up to $\$ 25,000$ per violation. Criminal penalties for knowing violations may climb as high as $\$ 50,000$ per violation and/or one-year imprisonment.

Courts are authorized to issue warrants and injunctive relief, as well as to commit searches and seizures to enforce the ESA. In addition, private citizens may bring suit against violators, including the government, or against the agencies to compel enforcement of the ESA. Agencies may even go as far as to make arrests for violations of the ESA. Also, any equipment or property used in the violation of the ESA may be declared forfeited and seized by the agencies.

\section{What Are the Exceptions to and Exemptions from the ESA?}

\section{Exceptions}

The federal agencies administering the ESA are authorized to grant exceptions, usually by way of takings permits, to the prohibitions against takings. Permits may be granted for the following:

- Scientific purposes (conservation/propagation of an endangered species).

- The taking of an endangered species, if such a taking is incidental to, and not the purpose of, the performance of an otherwise lawful activity.

In order to apply for a takings permit under the second rationale, the applicant must submit a Habitat Conservation Plan to either the Secretary of the Interior or the Secretary of Commerce, depending upon whether the endangered species to be taken is a land or an aquatic animal, or to the Secretary of Agriculture if the endangered species to be taken is a plant.

In the Habitat Conservation Plan, the applicant must specify (1) the impact that will likely result from the taking; (2) what steps the applicant will take to minimize and mitigate the impact, and the funding that will be available to implement such steps; (3) what the alternatives to the taking the applicant 
considered and the reasons why these alternatives are not being used; and (4) any other measures that the Secretary (of the Interior, Commerce, or Agriculture, depending on the type of endangered species which is taken) may require as being necessary or appropriate for purposes of the plan. The Secretary will issue the permit if the Secretary finds, after public notice and comment has been received, that the taking will be incidental; that the applicant will, to the maximum extent practicable, minimize and mitigate the impacts of the taking; that the applicant will ensure that adequate funding for the plan will be provided; that the taking will not appreciably reduce the probability of the survival and recovery of the species in the wild; and that all other additional measures required by the Secretary for the specific case, to be determined on a case-by-case basis, will be met. The permit can be revoked if it is found that the applicant is not complying with the terms and conditions of the permit.

\section{Exemptions}

There are several exemptions from the ESA, these include:

- The Hardship Exemption: This exemption is used in cases where the applicant has proven to the Secretary that the applicant had entered into a contract for the lawful taking of an animal or plant before it was placed on the endangered species list, and the listing will cause undue economic hardship to the applicant under the contract. Undue economic hardship includes substantial economic loss resulting from the inability to perform such contracts due to the listing of the species as endangered; substantial economic loss to people who for at least a year prior to the listing of the species derived a substantial portion of their income from the lawful taking of the now listed species; and the ending of the lawful taking of the species for food by people who are not reasonably able to secure other sources of food and who are substantially dependent on hunting and fishing for food. These permits are usually limited to allow takings only for one year following the designation of the species as endangered.
- The Antique Articles Exemption: Basically this exemption allows for the importation, exportation, transportation, possession, sale, and purchase in foreign and interstate commerce of antique articles made from threatened or endangered species (contact the EPA for a complete list of designated import ports and appropriate Customs import forms). This exemption covers only antique articles which:

- Are at least 100 years of age.

- Are composed in whole or in part of any listed threatened or endangered species.

- Have not been repaired or modified with any part of any listed species on or after December 28, 1973.

- Must be entered at one of the designated ports within the customs territory of the United States.

For the complete list of exemptions from the ESA please contact the EPA.

\section{The Hardship Exemption}

\section{The Antique Articles Exemption Source}

16 United States Code, Sections 1531 to 1544

\section{Acknowledgments}

The authors are indebted to the personnel of both state and federal agencies who provided their time and advice in the preparation of this handbook. The authors are especially indebted to Richard Budell of the Office of Agricultural Water Policy of the Florida Department of Agriculture and Consumer Services for providing funds for the development of this publication. 